\title{
Oleoylsalicylate Derivatives: Synthesis and Antifungal Activity
}

\author{
A. Bassoli ${ }^{1}$, G. Borgonovo ${ }^{*},{ }^{1}$ S. Caimi ${ }^{1}$, G. Farina ${ }^{2}$ and M. Moretti ${ }^{2}$
}

\author{
${ }^{I}$ Dipartimento di Scienze Molecolari Agroalimentari - DISMA, Sezione di Chimica, Università degli Studi di Milano,via \\ Celoria 2, 20133 Milano, Italy; ${ }^{2}$ Istituto di Patologia Vegetale, Università degli Studi di Milano,via Celoria 2, 20133 \\ Milano, Italy
}

\begin{abstract}
Three new "hybrid" molecules containing the skeleton of oleic acid and salicylic acid were synthesised. A qualitative study of the chemical stability of two of them and a preliminary evaluation of their biological activity in vivo and in vitro were performed against a series of important plant pathogens.
\end{abstract}

Keywords: Oleic acid, salicylic acid, vegetable oil, antifungal activity.

\section{INTRODUCTION}

Plants are persistently exposed to the attacks of several potentially damaging organisms, like fungi, bacteria and other pathogens, but only few of them can cause disease on each plant species. This is because plants can defend themselves from pathogen attacks by developing a variety of biochemical responses that can lead to what is called the hypersensitive reaction (HR) around the sites of attempted penetration, and blocking it. This local protective cell suicide can lead to another kind of defensive mechanism, called Systemic Acquired Resistance (SAR), that can be defined as a resistance to subsequent pathogen attacks that develops in the uninfected, pathogen free parts of the plant after the development of a necrotic lesion, as a consequence of an infection event or of an hypersensitive response [1]. SAR provides resistance to subsequent attacks, even by unrelated pathogens, for a relatively long period. Some low molecular weight proteins defined as Pathogenesis-Related (PR) are usually concomitantly synthesised. Since their discovery, these self-defence mechanisms and the chemical compounds that can trigger them have always drowned the attention of plant pathologists because of their potential utilization in crop protection. The aim to find products that could induce defence responses in plants has been pursued for a long time, leading to the development of plant resistance activators such as Probenazole, 2,2-dichloro-3,3-dimethylcyclopropane carboxylic acid (DDCC), (D,L)-3-Aminobutyric Acid, 2,6dichloroisonicotinic acid (INA) and benzothiadiazole (BTH) $[2,3]$.

Salicylic acid (SA) is a phenolic compound with an ubiquitous distribution in plants [4]. It is well established that SA, or its acetylated form acetylsalicylic acid, is a key signalling molecule in the induction of resistance to pathogens through HR and SAR and the production of some PR proteins in plants [5, 6]. It can induce resistance to biotic [7] and abiotic stresses [8] and there are some evidences that it possesses direct antifungal activity against some plant pathogens such as Eutypa lata [9] and Botrytis elliptica [10].

*Address correspondence to this author at the Dipartimento di Scienze Molecolari Agroalimentari - DISMA, Sezione di Chimica, Università degli Studi di Milano,via Celoria 2, 20133 Milano, Italy;

E-mail: gigliola.borgonovo@unimi.it
Fatty acid oils are reported to have antifungal activity too $[11,12]$, and their effectiveness against powdery mildews has been proved and recently confirmed [13,14]. This activity is due to a direct effect on the growth of fungi [15] and to an indirect effect through the activation of defence responses by the plant. In fact, these molecules are released from the membranes of plant cells by the trophic activity of insects and pathogens and act as precursors of elicitors, which activate the constitution of defensive barriers in the plants [16].

Therefore, salicylic acid and fatty acids share a potentially interesting antifungal activity and, moreover, they are particularly desirable because of their optimal properties of safety and inexpensiveness. From the molecular combination of salicyl phenols and free fatty acids, new "hybrid" derivatives can be obtained having the two moieties, joined through an ester bond. These new molecules could therefore maintain, or even increase the antifungal activity derived from their parent compounds through a synergic effect. As the antifungal activity of plant oils seems to be related to the presence of unsaturated fatty acids [12], oleic acid and its analogues must be considered as the best precursors for these synthetic purposes, as they are cheap and available with a good stability and ease of purification compared to the other polyunsaturated fatty acids.

The aim of this work was to develop and optimize the synthesis of new derivatives from oleic and salicylic acid, namely oleoylsalycil acid $\mathbf{1}$ and its analogues oleoylsalicylaldehyde 2 and oleoylsalycilic acid methyl ester 3 (Fig. 1). We also evaluated the antifungal activity of the new compounds, comparing it to that of their precursors (salicylic acid and oleic acid).

The chemical stability of the compounds was preliminarily studied in order to determine their putative persistence in the environment and their tendency to regenerate the precursors through hydrolytic reactions.

\section{MATERIALS AND METHODOLOGY}

\section{General Procedures}

NMR spectra were recorded with a Bruker AMX-300 instrument and the chemical shifts were expressed as $\delta$ value (ppm) relative to TMS as internal standard, J were in Hz. IR 
spectra were recorded on Perkin Elmer 1310 infrared spectrophotometer; MS spectra were recorded on Finnigan TSQ70 spectrometer equipped with an ICIS data system. For HPLC analysis, it was used a Varian PROSTAR instrument operating with a ternary pump, injector Rheodyne and a UVVIS double ray as revelatory system. HPLC column RP-18 Prevail $3 \mu \mathrm{m}, 150 \mathrm{~mm}$ ID $4.6 \mathrm{~mm}$, was used in a gradient condition for $\mathrm{CH}_{3} \mathrm{CN}$ and $\mathrm{H}_{2} \mathrm{O}$ at flow $1 \mathrm{mLmin}^{-1}$.<smiles>CCC=CCC(=O)Oc1ccccc1C(=O)OCc1ccccc1</smiles>

\begin{tabular}{lc}
\multicolumn{1}{c}{ Y } & compound \\
$\mathrm{OH}$ & $\mathbf{1}$ \\
$\mathrm{H}$ & $\mathbf{2}$ \\
$\mathrm{OCH}_{3}$ & $\mathbf{3}$
\end{tabular}

Fig. (1). Structure of hybrid molecules 1-3.

Flash chromatographies were done on Merk silica gel (230-400 mesh); solvents and reagents were of analytical grade. Solvents were dried by distillation, under nitrogen atmosphere in the presence of sodium for THF, and $\mathrm{CaH}_{2}$ for dichloromethane.

\section{Synthesis of New Derivatives}

The new analogues were obtained through an esterification reaction between the phenolic group of the salicylic derivatives and the carboxylic group of the oleic acid with two different methods (A and B). Method A consists of an esterification reaction under Steglich conditions (DCC and DMAP). In the first step of reaction, oleic acid was converted in the correspondent isourea by the addition of DCC and DMAP in dry dichloromethane, followed by the reaction with the phenolic derivatives: salicylic acid for compound $\mathbf{1}$, salicylic aldehyde for 2. Method B consists of an activation of the fatty acid by isobutylchloroformiate and NMM in dry THF, followed by a reaction with the correspondent phenol (Fig. 2). An alternative indirect preparation of product 1 based on oxidation of aldehyde $\mathbf{2}$, failed.

\section{Method A}

To a solution of oleic acid $(1.77 \mathrm{mmol})$ in $13 \mathrm{~mL}$ of dry dichloromethane under nitrogen atmosphere was added DCC $(1.77 \mathrm{mmol})$ and a catalytic amount of DMAP. The mixture was refluxed for $2 \mathrm{~h}$, then a solution of phenolic derivative in
$4 \mathrm{~mL}$ of dry dichloromethane and a few drops of DMF was added $(2.12 \mathrm{mmol})$. After $48 \mathrm{~h}$ of reflux the mixture was filtered and the solvent eliminated in vacuum obtaining a crude that was purified by flash chromatography.

\section{Method B}

To a solution of oleic acid (7.08 mmol) in dry THF under nitrogen atmosphere was added NMM $(35.4 \mathrm{mmol})$ and the reaction mixture was cooled to $0^{\circ} \mathrm{C}$. Isobutylchloroformiate $(7.78 \mathrm{mmol})$ was dropped and the reaction stirred at $0^{\circ} \mathrm{C}$ for $1 \mathrm{~h}$, then a solution of phenolic derivative $(7.08 \mathrm{mmol})$ in dry THF $(18 \mathrm{~mL})$ was added. The mixture was stirred at room temperature for two days then filtered on a celite pad and the solvent was eliminated at reduced pressure obtaining a crude product that was purified by flash chromatography.

Oleoylsalicylic acid 1

Yield 28\% (method A); 52\% (method B).

Rf 0.36 (hexane/AcOEt 75/25), HPLC: retention time 11.2 min (eluent $\mathrm{A}_{2} \mathrm{O}$, eluent $\mathrm{B} \mathrm{CH}_{3} \mathrm{CN}$, gradient conditions: $\mathrm{t}_{0} \mathrm{~A} / \mathrm{B}$ 15/85, $\mathrm{t}_{15 \min } \mathrm{A} / \mathrm{B}$ 7/93, flow $1 \mathrm{mLmin}^{-1}$, detector $231 \mathrm{~nm})$.

${ }^{1} \mathrm{H}-\mathrm{NMR}\left(\mathrm{CDCl}_{3}\right): \delta 0.9\left(\mathrm{t}, \mathrm{CH}_{3}, \mathrm{~J}=6.7 \mathrm{~Hz}, 3 \mathrm{H}\right), 1.2-1.5$ (s, b, 20H,), 1.78 (q, 2H-3', J = 7.2 Hz, 2H), 1.98 (s, b, 2H-8' and $\left.2 \mathrm{H}-11^{\prime}, 4 \mathrm{H}\right), 2.62(\mathrm{t}, 2 \mathrm{H}-2$ ', $\mathrm{J}=7.2 \mathrm{~Hz}, 2 \mathrm{H}), 5.37(\mathrm{~m}$, H-9' and H-10', 2H), 7.12 (dd, H-3, $J=8.02 \mathrm{~Hz}, \mathrm{~J}=1.15$ $\mathrm{Hz}, 1 \mathrm{H}), 7.38(\mathrm{dt}, \mathrm{H}-4, \mathrm{~J}=8.02 \mathrm{~Hz}, \mathrm{~J}=1.28 \mathrm{~Hz}, 1 \mathrm{H}), 7.60$ $(\mathrm{dt}, \mathrm{H}-5, \mathrm{~J}=7.46, \mathrm{~J}=1.75,1 \mathrm{H}), 8.12(\mathrm{dd}, \mathrm{H}-6, \mathrm{~J}=1.75 \mathrm{~Hz}, \mathrm{~J}$ $=7.80 \mathrm{~Hz}, 1 \mathrm{H})$.

MS m/z (\%): $401\left(\mathrm{M}^{-1}, 20\right), 387$ (30), 385 (100), 359 (23), 355 (28), 281 (10), 265 (10), 225 (32), 207 (5), 149 (7), 147 (30), 121 (100), 109 (25), 91 (85), 73 (80).

UV $\lambda \max (\mathrm{nm}): 238.9,275.9$. IR $1700,1780 \mathrm{~cm}^{-1}$. Oleoylsalicylaldehyde 2

Yield 30\% (method A); 72\% (method B).

$\mathrm{R}_{\mathrm{f}} 0.4$ (hexane/AcOEt 8/2), HPLC: retention time 16.7 min (eluent $\mathrm{A}_{2} \mathrm{O}$, eluent $\mathrm{B} \mathrm{CH}_{3} \mathrm{CN}$, gradient conditions: $\mathrm{t}_{0}$ $\mathrm{A} / \mathrm{B}$ 15/85, $\mathrm{t}_{15 \min } \mathrm{A} / \mathrm{B}$ 7/93, flow $1 \mathrm{mLmin}^{-1}$, detector 231 $\mathrm{nm})$.

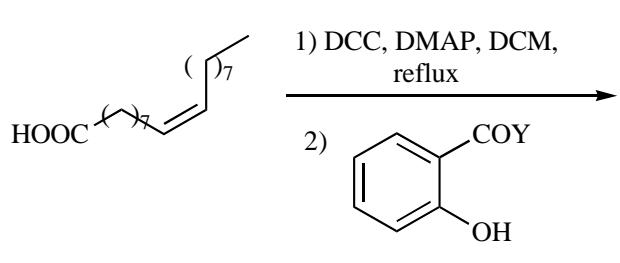

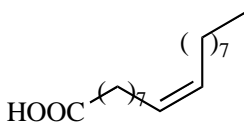

1) NMN, THF dry $0^{\circ} \mathrm{C}$<smiles>O=C(O)c1ccccc1O</smiles><smiles>CCC=CCC(=O)Oc1ccccc1C(=O)O</smiles><smiles>CCC/C=C\CCC(=O)Oc1ccccc1C(=O)O</smiles>

Fig. (2). Synthesis of derivatives. 
${ }^{1} \mathrm{H}-\mathrm{NMR}\left(\mathrm{CDCl}_{3}\right): \delta 0.9\left(\mathrm{t}, \mathrm{CH}_{3}, \mathrm{~J}=6.7 \mathrm{~Hz}, 3 \mathrm{H}\right), 1.2-1.5$ (s, b, 20H), 1.78 (q, 2H-3' J = 7.2 Hz, 2H), 1.98 (s, b, 2H-8' and $2 \mathrm{H}-11$ ', $4 \mathrm{H}), 2.65$ (t, 2H-2', J = 7.2 Hz, 2H), 5.37 (m, H9' and H-10', 2H), $7.12(\mathrm{dd}, \mathrm{H}-3, \mathrm{~J}=8.04 \mathrm{~Hz}, \mathrm{~J}=1.16 \mathrm{~Hz}$, $1 \mathrm{H}), 7.40$ (dt, H-4, J = 7.57 Hz, J = $1.16 \mathrm{~Hz}, 1 \mathrm{H}$ ), 7.55 (dt, $\mathrm{H}-5, \mathrm{~J}=7.45 \mathrm{~Hz}, \mathrm{~J}=1.75 \mathrm{~Hz}, 1 \mathrm{H}), 7.91(\mathrm{dd}, \mathrm{H}-6, \mathrm{~J}=7.80$ $\mathrm{Hz}, \mathrm{J}=1.75 \mathrm{~Hz}, 1 \mathrm{H}), 10.15$ (s, CHO, 1H).

MS m/z (\%): $386\left(\mathrm{M}^{+}, 10\right), 279$ (5), 264 (100), 239 (23), 236 (20), 211 (30), 183 (10), 151 (20), 121 (50), 98 (78).

IR $1710,1770 \mathrm{~cm}^{-1}$

Oleoylsalicylic acid methyl ester 3

Yield 10\% (method B).

$\mathrm{R}_{\mathrm{f}} 0.49$ (hexane/ $\mathrm{Et}_{2} \mathrm{O}$ 85/15) HPLC: retention time 17.2 min (eluent $\mathrm{A}_{2} \mathrm{O}$, eluent $\mathrm{B} \mathrm{CH}_{3} \mathrm{CN}$, gradient conditions: $\mathrm{t}_{0}$ A/B 15/85, $\mathrm{t}_{15 \min } \mathrm{A} / \mathrm{B} 7 / 93$, flow $1 \mathrm{mLmin}^{-1}$, detector 231 $\mathrm{nm})$.

${ }^{1} \mathrm{H}-\mathrm{NMR}\left(\mathrm{CDCl}_{3}\right): \delta 0.9\left(\mathrm{t}, \mathrm{CH}_{3}, \mathrm{~J}=6.64 \mathrm{~Hz}, 3 \mathrm{H}\right), 1.2-$ 1.5 (s, b, 20H), 1.78 (q, 2H-3', J = $7.45 \mathrm{~Hz}, 2 \mathrm{H}), 2.02$ (m, $2 \mathrm{H}-8^{\prime}$ and $2 \mathrm{H}-11$ ', $\left.4 \mathrm{H}\right), 2.65$ (t, $\left.2 \mathrm{H}-2^{\prime}, \mathrm{J}=7.45 \mathrm{~Hz}, 4 \mathrm{H}\right)$, 3.85 (s, COOMe, 3H), 5.37 (m, H-9' and $\left.\mathrm{H}-10^{\prime}, 2 \mathrm{H}\right), 7.12$ $(\mathrm{dd}, \mathrm{H}-3, \mathrm{~J}=8.04 \mathrm{~Hz}, \mathrm{~J}=1.16 \mathrm{~Hz}, 1 \mathrm{H}), 7.31(\mathrm{dt}, \mathrm{H}-4, \mathrm{~J}=$ $7.57 \mathrm{~Hz}, \mathrm{~J}=1.16 \mathrm{~Hz}, 1 \mathrm{H}), 7.58(\mathrm{dt}, \mathrm{H}-5, \mathrm{~J}=7.45 \mathrm{~Hz}, \mathrm{~J}=$ $1.75 \mathrm{~Hz}, 1 \mathrm{H}), 8.01(\mathrm{dd}, \mathrm{H}-6, \mathrm{~J}=7.80 \mathrm{~Hz}, \mathrm{~J}=1.75 \mathrm{~Hz}, 1 \mathrm{H})$.

MS m/z (\%): $416\left(\mathrm{M}^{+}, 5\right), 264$ (50), 236 (10), 165 (15), 152 (100), 120 (35), 120 (38), 95 (40), 81 (40), 69 (38), 55 (64). IR $1735,1770 \mathrm{~cm}^{-1}$

\section{Chemical Stability}

A preliminary study of stability, checked by HPLC, was performed on analogues $\mathbf{1}$ and $\mathbf{3}$ using Prevail RP18 column and UV detector calibrated on $231 \mathrm{~nm}$. Compounds $\mathbf{1}$ and $\mathbf{3}$ were dissolved $\left(1 \mu \mathrm{g} \mathrm{mL} L^{-1}\right)$ in DPGM and stored at room temperature and at $4^{\circ} \mathrm{C}$ for 3 days to check their stability day by day at different temperature conditions. The stability of compound 1 was also tested in methanol (at room temperature and at $4^{\circ} \mathrm{C}$ ) and acetone (at room temperature).

\section{Fungal Species}

The in vitro activity was tested on the oomycetes Phytophthora infestans (Mont.) de Bary and six phytopatogenic fungi: Botrytis cinerea Pers., Pyrenophora teres Drechsler, Sclerotinia sclerotiorum Bovary, Rhizoctonia solani Kühm, Cercosporella herpotricoides Fron. and Cercospora beticola Sacc. from the IPV Collection (Milan, Italy). All the pathogens were maintained on Potato Dextrose Agar Difco (PDA). Sphaerotheca fuliginea (Sch.) Solom (cucumber powdery mildew) and Uromyces appendiculatus (Pers.) Link. (bean rust) were grown on their host plants.

\section{Plants}

Cucumis sativus L. cv "Lungo della Cina" and Phaseolus vulgaris L. cv "Borlotto nano (Lingua di Fuoco)" used in this study were grown in plastic pots (diameter $11 \mathrm{~cm}$ ) in a growth room or greenhouse with artificial light $(14 \mathrm{~h}$ per days) at $22 \pm 2^{\circ} \mathrm{C}$ and $70 \pm 20 \% \mathrm{RH}$.

\section{Fungitoxicity}

Fungitoxicity was assessed both in vitro and in vivo. For the in vitro tests the compounds were assayed by the com- monly used poisoned food technique. Solutions were prepared by dissolving the appropriate amounts of each compound in $2 \mathrm{~mL}$ of $\mathrm{Me}_{2} \mathrm{SO}$ plus Tween 20 (2\%). Equal volumes of $\mathrm{Me}_{2} \mathrm{SO}$ containing diluted compounds were added to sterile cool PDA to give concentrations from 0.5 to 3.5 $\mathrm{mM}$ for each compound. Controls were treated with the solvent only. Amended media were inoculated with two mycelial plugs $(7 \mathrm{~mm})$ cut from the edge of actively growing colonies. Two replicate dishes were prepared for each concentration, together with toxicant-free media. The growth inhibition was calculated on the mean difference between treatment and control as a percentage of the latter.

Protectant and curative activities of compound $\mathbf{1}$ were evaluated with the in vivo against cucumber powdery mildew and the bean rust, while, for the other molecules, these activities were studied only against the cucumber powdery mildew. Cucumber plants were employed when the first true leaf was fully developed, while bean treatments were performed on plants maintained at the stage of well expanded primary leaves through shearing. Spores of Sphaeroteca fuliginea and Uromyces appendiculatus were obtained from their previously infected host plants. Plants inoculation was performed spraying on both the leaf surfaces; S. fuliginea spore suspensions $\left(1 \cdot 10^{5}\right.$ spore $\left.\mathrm{mL}^{-1}\right)$ in deionised water plus $0.01 \%$ Tween 20 ; for $U$. appendiculatus, the inoculum contained $2 \cdot 10^{5}$ uredospores $\mathrm{mL}^{-1}$ and, after inoculation, bean plants were kept for 24 hours at $100 \% \mathrm{RH}$ and then transferred to a growth room.

Compounds were dissolved in a mixture of deionised water $(80 \mathrm{~mL})$, and acetone $(20 \mathrm{~mL})$ with Tween $20(40 \mathrm{mg})$ as a surfactant. Fairly stable emulsions, which could be easily sprayed on the plant leaves, were obtained by agitation.

Protectant and curative activities were evaluated, on both the pathogens/host combinations, spraying homogenously 24 hours respectively before and after the inoculation with the corresponding pathogens leaf surfaces of seven plants of $C$. sativus and five plants of $P$. vulgaris with 0.5 to $5 \mathrm{mM}$ compound emulsions ( $7 \mathrm{mM}$ for salicylic and oleic acid).

Disease severity was recorded according to a six-point linear scale, from 0 to 5 with a $20 \%$ interval $(0=$ no symptoms and $5=100 \%$ diseased leaves). The compound activity was calculated as percentage of disease inhibition in comparison with the inoculated untreated plants.

\section{RESULTS AND DISCUSSION}

Two protocols of esterification have been developed to obtain the desired selectivity in ester formation through different types of activation of the carboxyl group.

In the design of new hybrid derivatives, we planned to link the two precursors through an ester bond between the phenolic hydroxyl of salicylic derivatives and the carboxylic function of the free fatty acid. Phenolic esters are less stable than aliphatic esters, and an easy hydrolytic behaviour could be foreseen for our salicyl conjugates. However, this is not necessarily a disadvantage, since the activity of these compounds could derive specifically from the in situ generation of the precursors, with the esters acting as a "prodrug".

The esterification of phenolic acids is not simple. The reaction is in fact complicated by the presence of the free carboxyl group and, even when this is protected or masked 


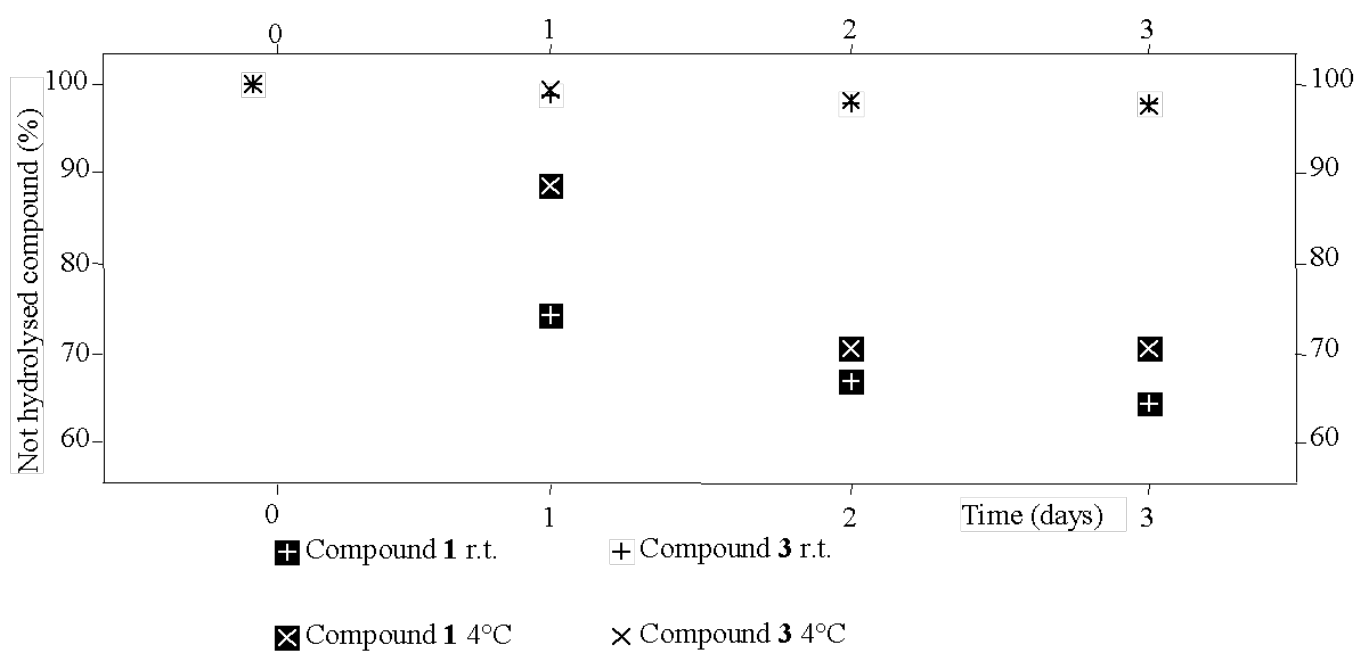

Fig. (3). Stability of compounds $\mathbf{1}$ and $\mathbf{3}$ dissolved in DPGM after 1, 2 and 3 days at different temperature conditions. r.t. $=$ room temperature.

as the corresponding ester or aldehyde, the reactivity is not very high due to electronic and steric effects. The first attempt to activate the oleic carboxyl with $\mathrm{PCl}_{3}$ or oxalylchloryde, failed, and thionyl chloride gave only very low yields $(24 \%)$ in compound $\mathbf{1}$. These reactions were also very sensitive to traces of moisture in the starting material, giving a very low reproducibility of the procedure.

For the synthesis of compounds $\mathbf{1}$ and $\mathbf{2}$ we used two methods named $\mathrm{A}$ and $\mathrm{B}$, while compound $\mathbf{3}$ was prepared only with method B. The synthetic procedures were optimised in order to increase the yields (Fig. 2) and to produce the compounds in gram-scale.

All compounds proved to be stable when stored without solvents. HPLC analysis of compounds $\mathbf{1}$ and $\mathbf{3}$ dissolved in DPGM and stored at different temperature conditions are reported in Fig. (3).

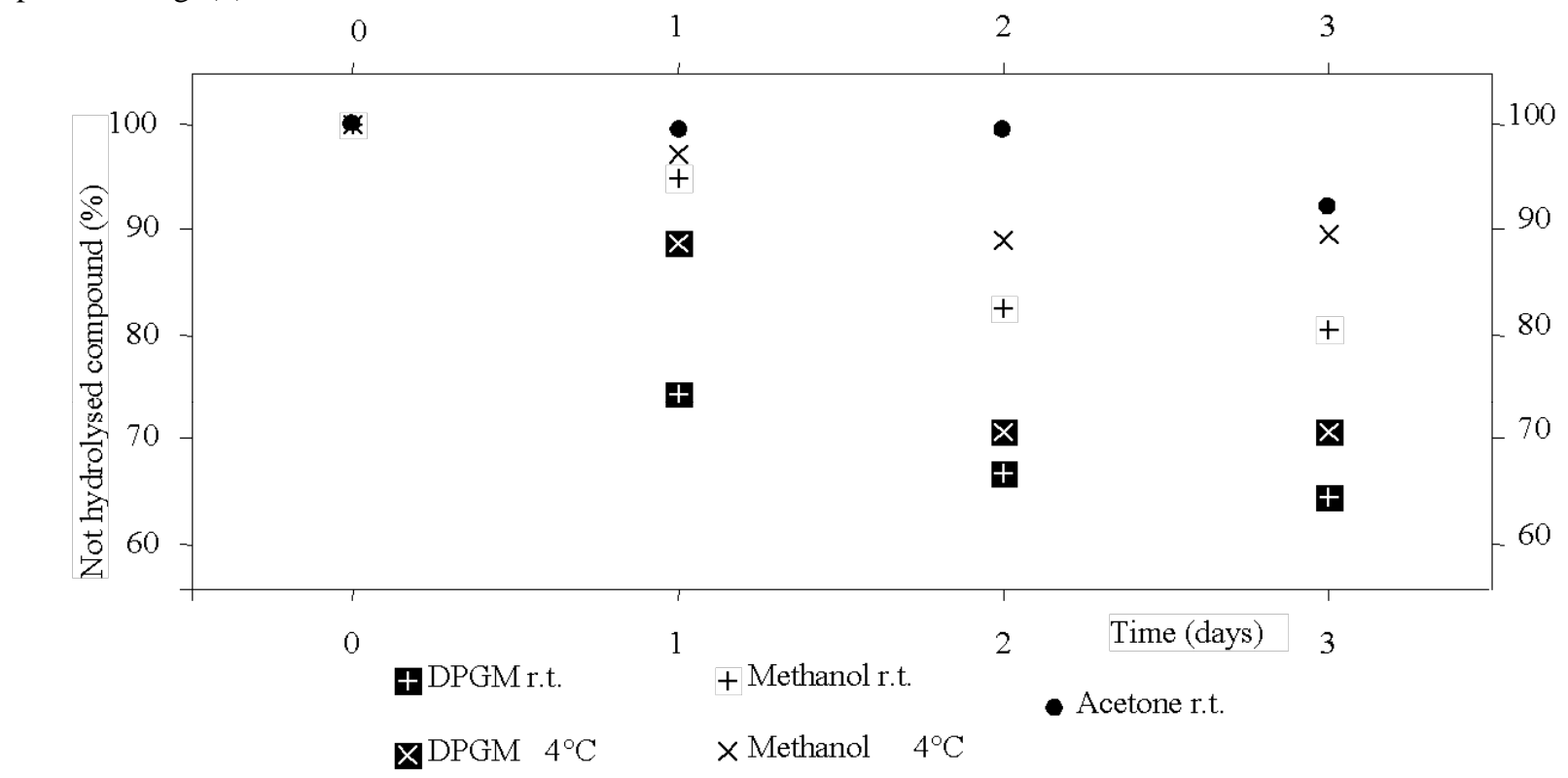

Fig. (4). Stability of compound 1 dissolved in DPGM, methanol and acetone after 1, 2 and 3 days at different temperature conditions. r.t. =

room temperature.
Compound $\mathbf{3}$ was very stable at both the tested temperature conditions. On the contrary, compound $\mathbf{1}$ showed a very rapid hydrolysation, which was steeper for samples stored at room temperature. To assess if the use of another solvent could increase its stability, two other solvents were tested, i.e. methanol and acetone (Fig. 4).

The use of acetone and, to a lesser extent, that of methanol, markedly increased the stability of compound $\mathbf{1}$, even at room temperature.

The antifungal activity of the compounds was evaluated both in vitro and in vivo against different phytopatogenic fungi, and was compared to that of their precursors oleic and salicylic acid. The in vitro tests were performed to assess a direct activity on the fungal growth complementary to the possible activation of the plant defence mechanisms. 


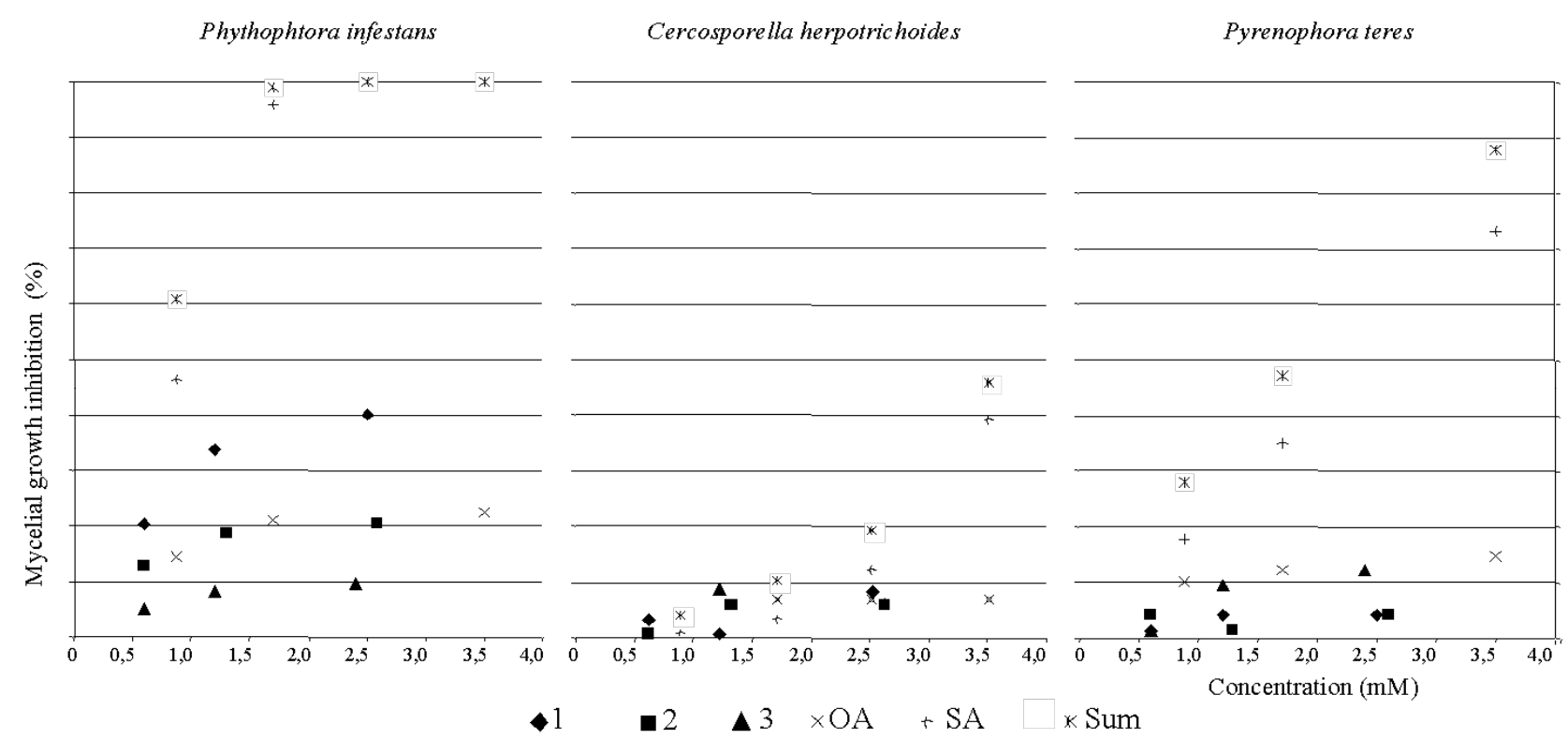

Fig. (5). In vitro antifungal activity of compounds 1, 2, 3, salicilyc acid (SA), oleic acid (OA) and their sum against $P$. infestans, $C$. herpotrichoides and P.teres.

The in vitro assays showed that both the conjugates and the parent compounds were mostly ineffective on $B$. cinerea, $S$. sclerotiorum, $R$. solani and $C$. beticola. Salicylic acid was effective in inhibiting the growth of some of the tested pathogens, particularly the oomycetes $P$. Infestans, whose mycelial growth was completely inhibited even at the lower tested concentrations, and, to a lesser extent, on P. teres and C. herpotrichoides (Fig. 5).

On the contrary, oleic acid was ineffective on most of the tested organisms, with the only exception of those already mentioned as the most sensitive to salicylic acid, namely $P$. infestans, $P$. teres and $C$. herpotrichoides, which were slightly inhibited. Growth inhibition curves induced by oleic acid on these fungi display a saturation kinetic with a plateau from the dose of $1.7 \mathrm{mM}$ at low inhibition levels as $7 \%$ for
C. herpotrichoides, $12 \%$ for $P$. teres and $22 \%$ for $P$. infestans. In fact, these data agree with those reported by Walters and co-workers (2004) [15], who found a minor effectiveness of this fatty acid with respect to linolenic and linoleic ones.

Compounds 1, 2 and $\mathbf{3}$ were completely ineffective against $B$. cinerea, $S$. sclerotiorum and $R$. solani, and less effective than their precursors on the other fungal strains investigated. $P$. infestans was the most sensitive organism within the ones assayed, and $\mathbf{1}$ the most active product, followed by compound $\mathbf{2}$ and 3. Fig. (5) shows that all these compounds are less effective not only with respect to the sum of the activity of oleic and salicylic acids, but even to that of salicylic acid alone, as if the presence of the fatty acid chain could mask the activity of the salicylic moiety. Com-

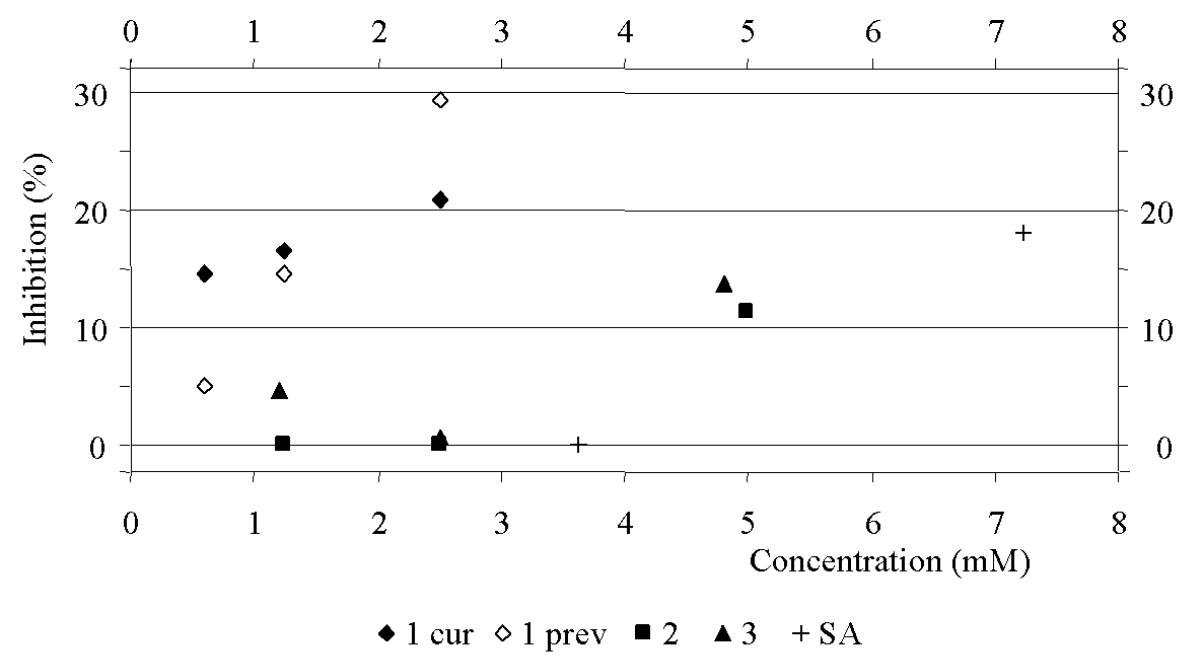

Fig. (6). In vivo curative (compounds 1, 2, 3 and salicylic acid) and preventive (compound 1) activity on S. fuliginea expressed as percent growth inhibition. 
pounds 1-3 were even less effective on $P$. teres than oleic acid itself, with $\mathbf{3}$ being, however, more active than compound 1. The saturation kinetics was similar for all compounds.

Protectant and curative activities of 1, 2 and 3 and of their precursors were evaluated in vivo against cucumber powdery mildew (Sphaerotheca fuliginea/Cucumis sativus) and the bean rust (Uromyces appendiculatus/Phaseolus vulgaris.), treating the plants at concentrations ranging from 0.6 to $7 \mathrm{mM}$, respectively for $24 \mathrm{~h}$ before and after the inoculation. $U$. appendiculatus was totally insensitive to all the molecules in all the tested conditions. With respect to $S$. fuliginea, the activity of the precursors was null in the preventive treatments, while in the curative ones, salicylic acid had a weak effect only at $7 \mathrm{mM}$. Higher doses induced phytotoxicity symptoms. Oleic acid has always been completely ineffective. The newly synthesized compounds generally had no effect in the preventive treatment of cucumber plants. Only compound 1 mildly inhibited the development of the pathogen $(29,3 \%$ at higher concentration) (Fig. 6). Further trials performed to verify the hypothesis that molecule $\mathbf{1}$ could elicit some defence mechanisms in plants, challenged by early and repeated treatments did not improve its performance (data not shown).

The curative application of compounds $\mathbf{1 , 2}$ and $\mathbf{3}$ always gave better results than the preventive ones, and all compounds performed better than the salicylic acid. This suggests that the presence of the carboxyl group is important to elicit a direct toxicity effects on fungi, but is not necessarily triggers the defence response by the challenged plants. Moreover, the carboxyl group is probably not generated in situ through oxidative and/or hydrolitic processes from the aldehyde and methyl ester respectively, as we could had surmised, since, in this case, we should have noted some activity also in the compounds $\mathbf{2}$ and $\mathbf{3}$.

In conclusion, hybrid salicyl-oleoyl conjugates proved to be slightly effective only against $S$. fuliginea in vivo. Further studies must be done to improve this activity, for example using more effective fatty acids like the linoleic or the linolenic ones as precursors, and assaying other host/pathogen combinations.

\section{ACKNOWLEDGEMENTS}

We would like to thank Elio Burrone for his helpful contribution to the in vitro and in vivo activity tests.

$\begin{array}{ll}\text { ABBREVIATIONS } \\ \text { DCC }= & \text { dicyclohexylcabodiimide } \\ \text { DMAP }= & \text { 4-Dimethylaminopyridine } \\ \text { NMM }= & \text { N-methylmorfoline } \\ \text { THF }= & \text { tetrahydrofuran } \\ \text { DPGM } & \text { dipropylenglycolmethylether } \\ \text { DMF }= & \text { dimethylformamide. }\end{array}$

\section{REFERENCES}

[1] Hammerschmidt, R. Physiol. Mol. Plant Pathol. 1999, 55, 77-84.

[2] Oostendorp, M.; Kunz, W.; Dietrich, B.; Staub, T. Eur. J. Plant Pathol. 2001, 107, 19-28.

[3] Gozzo, F. J. Agr. Food Chem. 2003, 51, 4487-4503.

[4] Raskin, I. Plant Physiol. 1992, 99, 799-803.

[5] Enyedi, A. J.; Yalpati, N.; Silverman, P.; Raskin, I. Proc. Natl. Acad. Sci. USA 1992, 89, 2480-2484.

[6] Yalpani, N.; Silverman, P.; Wilson, T. M. A.; Kleier, D. A.; Raskin, I. Plant Cell 1991, 3, 809-818.

[7] White, R. F. Virology 1979, 99, 410-412.

[8] Mhiri, C.; Morel, J. B.; Vernhettes, S.; Casacuberta, J. M.; Lucas, H.; Granbastein, M.A. Plant Mol. Biol. 1997, 33(2), 257-266.

[9] Amborabé, B.-E.; Fleurat-Lessard, P.; Chollet, J.-F.; Roblin, G. Plant Physiol. Bioch. 2002, 40, 1051-1060.

[10] Lu, Y. Y.; Chen, C. Y. Plant Sci. 2005, 169, 1-9.

[11] Sekizawa, Y.; Shimura, M.; Suzuki, A.; Iwata, M. Agric. Biol. Chem. 1981, 45(6), 1437-1439.

[12] Mori, A.; Enoki, N.; Shinozuka, K.; Nishino, C.; Fukushima, M. Agric. Biol. Chem. 1987, 51(12), 3403-3405.

[13] Pasini, C.; D’Aquila, F.; Curir, P.; Gullino, M. L. Crop Prot. 1997, 16(3), 251-256.

[14] Zerbetto, F.; Maffi, D.; Sburlino, P.; Fremiot, P. In Attività antioidica su vite di alcuni olii vegetali e minerali utilizzati da soli o con bicarbonato di sodio. Atti Giornate Fitopatologiche, Montesilvano (Pescara), Italy, May 2004.

[15] Walters, D.; Raynor, L.; Mitchell, A.; Walker, R.; Walker, K. Mycopathologia 2004, 157, 87-90.

[16] Lucas, J. A. In Plant Pathology and Plant Pathogens III. Blackwale Science: Oxford, 1998, pp. 160-165. 